\title{
ADA APA DENGAN PONDOK WISATA? SELUK BELUK KEBERADAAN PONDOK WISATA DI UBUD
}

\author{
Wahyuni Dwi Pratiwi ${ }^{\mathrm{a}, 1}$, I Made Sukana ${ }^{\mathrm{a}, 2}$ \\ 1'wahyunidwipratiwi@gmail.com, ${ }^{2}$ sukana.made@gmail.com \\ a Program Studi S1 Destinasi Pariwisata, Fakultas Pariwisata,Universitas Udayana, Jl. Dr. R. Goris, Denpasar, Bali 80232 Indonesia
}

\section{Abstract}

Along with the increasing number of tourists who visited Ubud, the growth of facilities that provided for tourists to stay in Ubud is also growing rapidly. This is evidenced by the proliferation of the existing lodges. So this study evaluated the existence of lodges in Ubud today. In determining the lodges to be studied, the technique that used is random technique which is assisted by random.org program. The method of observation and in-depth interviews is used for collecting data whereas descriptive qualitative is used for analyzed the data.

The finding identify that the existence lodges in Ubud preceded by a lodge named Tjanderi Homestay. Until the year 2012 the number of lodges in Ubud has been increased significantly by as much as 445 lodges scattered throughout the Ubud district. Most of that lodges were built in the teba (backyard). In promote their lodges, the owners use conventional networks such as information mouth to mouth, guide networking and networking among local lodge owners. Traditional marketing is combined with modern networks such as Global Distribution System and website. Beside of that, the competition in terms of facilities, marketing and the competition in terms of price are also still be found.

Keywords: Lodges, Existenc

\section{PENDAHULUAN}

Ubud merupakan sebuah destinasi wisata budaya yang terkenal di Bali. Daya tarik wisata budaya Ubud ini, menyebabkan banyak wisatawan yang berkunjung dan bahkan tinggal sementara di tempat ini untuk merasakan suasana Ubud yang sarat akan budaya tersebut. Berdasarkan data Polsek Ubud tahun 2012, terhitung sebanyak 70.258 wisatawan asing yang menginap di Ubud pada tahun tersebut.

Dengan banyaknya jumlah wisatawan yang menginap di Ubud, banyak pihak yang akhirnya memanfaatkan hal ini dengan menyediakan akomodasi sebagai tempat tinggal sementara wisatawan selama mereka berwisata dan bahkan ada juga ada yang rela menyewakan rumahnya untuk ditempati oleh wisatawan. Usaha akomodasi yang terdapat di Ubud sangat bervariasi, mulai dari pondok wisata, hotel melati hingga hotel berbintang. Untuk lebih jelasnya mengenai jumlah masingmasing akomodasi di Ubud, dapat dilihat pada tabel berikut
Tabel 1.1

Jumlah Akomodasi di Ubud Tahun 2012

\begin{tabular}{|c|l|c|c|}
\hline No. & Jenis Akomodasi & Jumlah & $\begin{array}{c}\text { Persentase } \\
(\%)\end{array}$ \\
\hline 1. & Hotel Berbintang & 12 & 1,97 \\
\hline 2. & Hotel Melati & 152 & 24,96 \\
\hline 3. & Pondok Wisata & 445 & 73,07 \\
\hline \multicolumn{2}{|c|}{ Total } & 609 & 100 \\
\hline
\end{tabular}

Sumber: Data Jumlah Perusahaan Perkantoran, Pabrik, Jasa Perhotelan dan Restoran, Polsek Ubud 2012.

Dari tabel tersebut terlihat bahwa jenis akomodasi pondok wisata merupakan yang terbanyak di Ubud yaitu mencapai $73,07 \%$. Hal ini sebagai bukti bahwa masyarakat lokal Ubud memiliki cara mereka sendiri dalam menyikapi perkembangan pariwisata di tanah kelahirannya tersebut. Sejak awal kemunculannya, pertumbuhan pondok wisata di Ubud selalu menunjukkan peningkatan yang signifikan. Bahkan hal ini telah berhasil mengubah wajah Ubud yang dulunya masih dipenuhi pohon-pohon hijau yang alami, kini telah disesaki oleh beton-beton yang berdiri kokoh. Berdasarkan hal tersebut maka diperlukan suatu kajian mengenai bagaimanakah keberadaan pondok wisata di Ubud sebagai sarana akomodasi dewasa ini.

Tulisan ini berupaya memberikan penjelasan mengenai keberadaan pondok wisata di Ubud sebagai sarana akomodasi dewasa ini, dimana hal 
tersebut sangat berguna bagi pengelola pondok wisata di Ubud untuk keberlangsungan usahanya. Selain itu penelitian ini dapat memberikan manfaat secara akademis kepada mahasiswa dalam menambah wawasan dan dapat mengimplementasikan ilmu yang telah didapat di bangku kuliah.

\section{PONDOK WISATA DI UBUD}

Berdasarkan Perda Provinsi Daerah Tingkat I Bali No. 13 Tahun 1989 Tentang Usaha Pondok Wisata, yang dimaksud dengan pondok wisata adalah sebagai berikut:

"Usaha Pondok Wisata adalah suatu usaha perseorangan dengan menggunakan sebagian dari rumah tinggalnya untuk penginapan bagi setiap orang dengan perhitungan pembayaran harian"

Berdasarkan Data Jumlah Perusahaan Perkantoran, Pabrik, Jasa Perhotelan dan Restoran Tahun 2012 yang dipublikasikan oleh Polsek Ubud, yang termasuk kedalam pondok wisata adalah homestay, house, villa, inn, cottage, bungalow dan accommodation.

Sebelumnya, salah satu penelitian yang menjadikan pondok wisata sebagai objek penelitiannya adalah penelitian yang dilakukan oleh Sukana (2002). Dalam tulisannya, Sukana melihat pertumbuhan pondok wisata di Kuta merupakan wujud dari tanggapan masyarakat dalam melihat perkembangan pariwisata di Kuta. Hal ini tercermin oleh pernyataan Sukana dalam tulisannya berikut ini.

"Kehadiran para "hippies" ini dimanfaatkan oleh penduduk setempat untuk membuka usaha penyewaan rumah, sepeda, sepeda motor dan membuka warung-warung makanan yang menyediakan berbagai kebutuhan wisatawan. Usaha ini menyebabkan munculnya usaha baru seperti: homestay, pension, inn, bar dan restoran. Sejak itu, penduduk Kuta semakin banyak yang terlibat dalam kegiatan kepariwisataan ini."

Lebih jauh Sukana menemukan bahwa keberadaan pondok wisata di Kuta sudah mulai disesaki oleh hotel-hotel berskala besar. Hal ini akhirnya menyebabkan timbul beberapa permasalahan yang menghambat perkembangan pondok-pondok wisata di Kuta dan berujung pada beralih fungsinya beberapa pondok wisata tersebut. Beberapa diantaranya beralih menjadi usaha restoran dan dijadikan kos-kosan, sementara beberapa yang lainnya kembali ke fungsi awalnya sebagai rumah tinggal pribadi.

Dari penelitian ini Sukana juga mendapatkan hasil berupa karakteristik pondok wisata di Kuta yang cenderung dibangun ke pelosok-pelosok gang kecil di Kuta dan umumnya menyediakan fasilitas yang sangat sederhana dengan menyediakan kamar serta sarapan bagi wisatawan. Para pengelola pondok wisata di Kuta ini juga masih mempromosikan usahanya tersebut dari mulut ke mulut.

Dalam penelitian di Ubud ini, juga dilakukan penelitian yang hampir menyerupai dengan apa yang dilakukan oleh Sukana (2002), hanya saja lokasi penelitian ini berada di Ubud, dimana pariwisata di daerah ini berkembang sangat pesat seperti halnya perkembangan pariwisata di Kuta. Penelitian ini akan terfokus pada usaha pondok wisata yang ada di Ubud dengan mengkaji keberadaan pondok wisata di Ubud dewasa ini, persoalan-persoalan yang membelit pondok wisata di Ubud dalam pengelolaannya serta strategi mereka untuk bertahan.

Penelitian lainnya yang meneliti mengenai pondok wisata dilakukan oleh Tyas (2008). Dalam tulisannya Tyas mengungkapkan bahwa perkembangan pondok wisata yang merupakan usaha kecil yang dimiliki oleh hampir semua warga kawasan Ubud dikhawatirkan memberi dampak pada lingkungan biofisik, sosial, ekonomi dan juga budaya dikarenakan kurangnya informasi dan kurangnya pengetahuan pengelola mengenai pengelolaan pondok wisata yang ramah lingkungan serta belum adanya perhatian penuh dari pemerintah. Hasil penelitian menunjukkan bahwa $7 \%$ pondok wisata dikatagorikan ramah lingkungan, 23\% dikategorikan dalam upaya mengelola lingkungan dan $70 \%$ pondok wisata dikategorikan belum melakukan upaya mengelola lingkungan. Kendala dominan yang dihadapi oleh pengelola yaitu tidak adanya akses informasi mengenai pengelolaan ramah lingkungan.

Penelitian yang dilakukan oleh Tyas dan penelitian yang dilakukan ini memiliki kesamaan lokasi penelitian yaitu sama-sama berlokasi di Ubud dan sama-sama meneliti pondok wisata, namun yang menjadi fokus penelitiannya berbeda, yang mana penelitian Tyas meneliti mengenai dampak dari perkembangan pondok wisata, sedangkan penelitian sekarang memiliki fokus mengenai keberadaan pondok wisata dewasa ini.

Untuk mengetahui pada tahap manakah perkembangan pariwisata Ubud saat ini, akan dianalisis menggunakan teori tourism area life cycle. Menurut Butler dalam Gian (2013) siklus tourism area life cycle adalah sebagai berikut. 


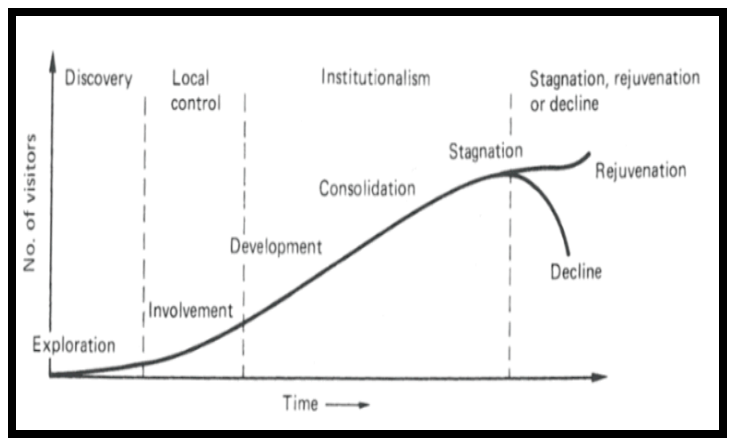

Gambar 2.1. Tourism Area Life Cycle Sumber: Gian, 2013

1. Eksplorasi (Exploration): Sebuah area wisata baru ditemukan oleh seseorang. Mulai dikunjungi oleh wisatawan walaupun dengan jumlah yang sangat sedikit. Area wisata ini umumnya masih alami dan belum ada fasilitas wisata bagi wisatawan.

2. Keterlibatan (Involvement): Jumlah kunjungan wisatawan mulai memperlihatkan peningkatan terutama pada hari-hari libur. Pemerintah dan masyarakat lokal mulai ikut terlibat dalam menunjang kegiatan kepariwisataan di area wisata tersebut. Kontribusi yang diberikan oleh pemerintah dan masyarakat lokal misalnya menyediakan fasilitas-fasilitas wisata, berinteraksi dengan wisatawan, hingga mempermudah akses masuk walau dengan skala yang terbatas. Mulai dilakukan promosi-promosi berskala kecil untuk semakin memperkenalkan area wisata yang bersangkutan.

3. Pembangunan (Development): Jumlah kunjungan wisatawan semakin meningkat. Banyak investor asing dan lokal dari luar yang berlomba-lomba menanamkan modalnya. Bermunculannya organisasi pariwisata, fasilitas pariwisata yang lebih memadai, penyedia jasa pelayanan wisata asing dan atraksi wisata buatan. Masuknya tenaga kerja asing dan barang-barang impor guna menyesuaikan keinginan wisatawan.

4. Konsolidasi (Consolidation): Jumlah kunjungan wisatawan masih naik walau tidak terlalu signifikan. Kegiatan ekonomi diambil alih oleh perusahaan-perusahaan jaringan internasional. Berbagai macam fasilitas wisata dirawat, diperbaiki, dibangun dan ditingkatkan standarnya. Promosi semakin sering dilakukan.
5. Stagnasi (Stagnation): Jumlah kunjungan wisatawan telah mencapai puncak tertingginya. Atraksi wisata alami sudah disesaki dengan atraksi wisata buatan yang berdampak pada berubahnya citra awal area wisata tersebut.

6. Penurunan (Decline): Fasilitas wisata yang ada beralih fungsi dari fungsi awalnya. Wisatawan mulai jenuh dengan atraksi wisata yang ada.

7. Peremajaan (Rejuvenation): Muncul inovasiinovasi baru. Area wisata di tata ulang sehingga memberikan warna baru.

\section{METODE PENELITIAN}

Penelitian ini dilakukan di kawasan pariwisata Ubud yang lebih difokuskan di Kelurahan Ubud dan Desa Padang Tegal. Lokasi-lokasi ini dipilih karena berbagai pertimbangan, yaitu:

a. Kelurahan Ubud serta Desa Padang Tegal merupakan wilayah di Ubud yang pertumbuhan pondok wisatanya paling tinggi.

b. Awal mula berdirinya pondok wisata di Ubud, diawali oleh sebuah pondok wisata yang ada di lokasi penelitian ini.

c. Pondok wisata yang ada di lokasi penelitian ini sangat beragam, mulai dari yang berskala kecil dan masih dikelola oleh keluarga pemilik pondok wisata tersebut hingga yang berskala besar dan telah dikelola dengan manajemen yang profesional.

Keberadaan pondok wisata di Ubud sebagai sarana akomodasi dewasa ini yang dimaksud adalah persebaran pondok wisata di Kelurahan Ubud dan Desa Padang Tegal yang merupakan daerah di Ubud dengan usaha pondok wisata yang sangat padat. Aspek data yang dicari adalah bagaimana awal mula berdirinya pondok wisata di Ubud serta bagaimana perkembangannya, jumlah pondok wisata di Ubud, karakteristik pondok wisata di Ubud, karakteristik karyawan, jejaring pemasaran dan persaingan.

Pengumpulan data dalam penelitian ini dilakukan dengan wawancara mendalam. Wawancara mendalam dilakukan dengan berpedoman pada pedoman wawancara yang digali dan dirumuskan melalui observasi pendahuluan/assessment. Beberapa hal yang ditanyakan diantaranya adalah jumlah pondok wisata di Ubud, jejaring pemasaran serta persaingan yang dirasakan.

Selain wawancara mendalam, pengumpulan data juga dilakukan dengan observasi baik di lokasi yang menjadi sampel maupun di beberapa lokasi pondok wisata di sekitarnya. Hal-hal yang diobservasi diantaranya lokasi fisik akomodasi, fasilitas fisik yang disediakan, dan jejaring kerja. 
Informan dalam penelitian ini dipilih secara random dengan pertimbangan bahwa informan pangkal (Kelian Banjar) mengalami kesulitan dalam membantu peneliti untuk menentukan informan kunci yang terkait dengan permasalahan dan tujuan penelitian. Atas pertimbangan itu, maka peneliti mencari sumber informasi subjek penelitian ini dari data jumlah perusahaan perkantoran, pabrik, jasa perhotelan dan restoran tahun 2012 yang telah dikumpulkan oleh Polsek Ubud. Informasi keberadaan data ini diperoleh berdasarkan saran dari Kelian Banjar Ubud Tengah. Berdasarkan data dari Polsek Ubud inilah pemilihan sampel pondok wisata ditentukan secara random dengan bantuan program random.org. Dari hasil random tersebut diperoleh lokasi-lokasi yang menjadi subjek penelitian ini. Informan kunci selanjutnya diambil dan ditentukan dari pemilik pondok wisata maupun para staf (front office, housekeeping dan bagian informasi) dari Taman Sakti, Sunarta House Homestay, Dharma Sakti Bungalows, Ketut's Place, Rahayu Bungalows, Indraprastha Bungalows, Arsa Homestay, Wayan Family Homestay, Lumbung Sari Cottages, Puri Muwa Garden, Puri Ulun Carik, Lecuk Inn, dan Rumah Roda. Keseluruhan informan kunci ini berjumlah 13 orang

Data yang telah dikumpulkan dianalisis menggunakna teknik analisis kualitatif. Menurut Biklen,et.al. (dalam Moleong, 2005) teknik analisis data kulaitatif adalah upaya yang dilakukan dengan jalan bekerja dengan data, mengorganisasikan data, memilah-milahnya menjadi satuan yang dapat dikelola, mensintesiskanya, mencari dan menemukan pola, menemukan apa yang penting dan apa yang dipelajari, dan memutuskan apa yang dapat diceritakan kepada orang lain.

\section{POTRET WILAYAH UBUD}

Secara geografis, Kelurahan Ubud berada dalam jarak $12 \mathrm{~km}$ dari ibukota Gianyar. Kelurahan Ubud merupakan salah satu kelurahan yang ada di Kecamatan Ubud, dengan batas-batas wilayah sebagai berikut:
Di sebelah Utara
: Desa Tegalalang.
Di sebelah Timur
: Desa Peliatan.
Di sebelah Selatan : Desa Mas
Di sebelah Barat
: Desa Sayan

Kedatangan seorang pria berkewarganegaraan Rusia yang lahir di Jerman bernama Walter Spies ke Ubud pada tahun 1925 merupakan hal yang sangat penting bagi perkembangan pariwisata Ubud. Beliau merupakan promotor pertama yang memperkenalkan Ubud pada dunia global melalui kemahirannya dalam melukis, fotografi serta keahliannya dalam membuat film. Semua hasil karyanya itu memberi keuntungan bagi Ubud yang menjadikan daerah ini semakin terkenal dan pariwisatanya pun semakin berkembang.

Hingga sekarang sepotong kue pariwisata Bali ini masih dapat dinikmati oleh masyarakat lokal Ubud dengan mendapatkan keuntungan dari membuka berbagai usaha di bidang pariwisata. Tak ketinggalan kelompok-kelompok yang terpinggirkan dari pusat kegiatan pariwisata Ubud ini juga mendapat bantuan dari pelaku-pelaku pariwisata yang ada di Ubud seperti melalui program bedah rumah. Bahkan sekelompok anjing liar yang diwadahi oleh Yayasan Bawa pun juga mampu merasakan manisnya kue pariwisata Ubud ini.

\section{KEBERADAAN PONDOK WISATA SEBAGAI SARANA AKOMODASI DI UBUD DEWASA INI}

Jika dilihat berdasarkan Teori tourism area life cycle, perkembangan Ubud sebagai sebuah destinasi wisata saat ini berada pada tahap stagnasi. Hal ini juga sesuai dengan pendapat Gian (2013) berdasarkan penelitian yang ia lakukan di Ubud sebagai berikut:

"Dalam kasus Ubud sebagai destinasi pariwisata bila dikaitkan dengan teori ini adalah berada pada fase stagnation yang berarti perkembangan pariwisata Ubud telah pada tingkat puncaknya."

Lebih lanjut Gian mengatakan bahwa hal ini dapat dilihat dari akumulasi jumlah bangunanbangunan di Ubud yang menyebabkan destinasi pariwisata ini semakin padat dan akhirnya berakibat pada banyaknya praktek alih fungsi lahan. Hal ini tercermin dari tulisannya berikut ini.

"Stagnasi dalam kasus Ubud terlihat jelas dari pemanfaatan ruang (space) yang semakin tidak memperhatikan daya dukung (carrying capacity). Perlu dicermati bahwa Ubud merupakan suatu wilayah yang mempunyai daya tampung relatif kecil jika dilihat dari fisiknya."

Tahap stagnasi ini juga terlihat dari banyaknya usaha-usaha berbau internasional yang mulai menjamur di beberapa sudut Ubud. Ini merupakan jawaban atas permintaan beberapa wisatawan asing yang menginginkan agar kebutuhan mereka selama di Ubud sesuai dengan standar di negaranya dengan kata lain kebutuhan tersebut haruslah sesuai dengan standar internasional. Hal ini sejalan dengan pendapat Gian dalam tulisannya berikut ini. 


\section{Vol. 4 No. 1, 2016}

"Bukti nyata yang dapat dipertimbangkan adalah kunjungan wisatawan baik domestik maupun internasional terus meningkat, hotel-hotel franchise dari luar negeri sudah banyak dibangun dan beroperasi seperti Westin dan Four Season, toko-toko pakaian banyak berasal dari luar negeri, tata ruang pembangunan di Ubud semakin padat yang mengakibatkan ruang gerak masyarakat dan wisatawan kian menyempit, kendaraan yang bertambah serta mulai terjadinya beberapa aksi kriminal yang telah terdengar di media masa."

Selain dari bukti-bukti yang ditemukan Gian dalam penelitiannya tersebut, kini berbagai objek dan daya tarik wisata alam yang terdapat di Ubud juga mulai disesaki berbagai atraksi wisata buatan seperti Museum.

Disamping itu wisatawan yang berkunjung ke Ubud juga sudah mulai mengeluh tentang kemacetan di pusat-pusat pariwisata Ubud, dimana hal ini juga menjadi salah satu indikator hingga akhirnya destinasi wisata ini disimpulkan berada pada tahap stagnasi sesuai dengan tulisan Gian sebagai berikut:

"Selain itu, degradasi kualitas dan kuantitas akses karena meningkatnya lalu lintas pariwisata yang masuk ke dalam pusat pariwisata Ubud dan banyaknya pendatang yang mencari penghasilan di Ubud berakibat pada kurangnya kenyamanan dan keamanan wisatawan."

\section{a. Bermula dari seorang Tjanderi}

Menurut Perda Provinsi Daerah Tingkat I Bali Nomor 13 Tahun 1989 Tentang Usaha Pondok Wisata, telah dijelaskan sebagai berikut:

"Usaha Pondok Wisata adalah suatu usaha perseorangan dengan menggunakan sebagian dari rumah tinggalnya untuk penginapan bagi setiap orang dengan perhitungan pembayaran harian"

Hal inilah yang dilakukan oleh $\mathrm{Ni}$ Made Canderi. Ia menggunakan bagian belakang rumahnya untuk membangun kamar-kamar yang disediakan bagi wisatawan. Tjanderi Homestay merupakan pondok wisata pertama di Ubud yang sudah menuju ke arah komersial yang terbukti dengan mulai memungut bayaran bagi setiap wisatawan yang menginap di pondok wisata ini.

Homestay ini dibuka oleh $\mathrm{Ni}$ Made Canderi pada tahun 1970, tepat 23 tahun setelah Puri Ubud menerima wisatawan pada tahun 1947 yang mendapat rekomendasi dari Rudolf Bonnet. Akomodasi ini dulu dibangun di belakang pasar dari jalan utama di Ubud (sekarang Jalan Raya Ubud).

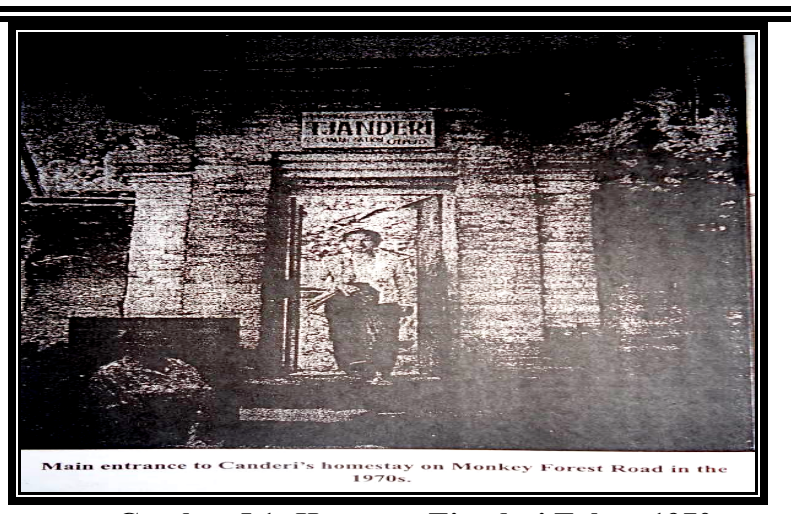

Gambar 5.1. Homestay Tjanderi Tahun 1970

Sumber: The Making of Ubud, Richard Mann, 2013

Kini mendekati umur 80 tahun, Canderi tetap mengoperasikan homestay-nya di rumah modernnya yang terletak di Jalan Wenara Wana, beberapa meter dari pasar dan tempat dimana sejarah pariwisata Ubud dimulai.

Untuk melihat lebih jelas bagaimana perbandingan keadaan Ubud di tahun 1970-an ketika pariwisata baru saja dikenal di Ubud dengan keadaan Ubud saat ini, berikut adalah peta sketsa Ubud di tahun 1974 dan peta sketsa Ubud tahun 2013.

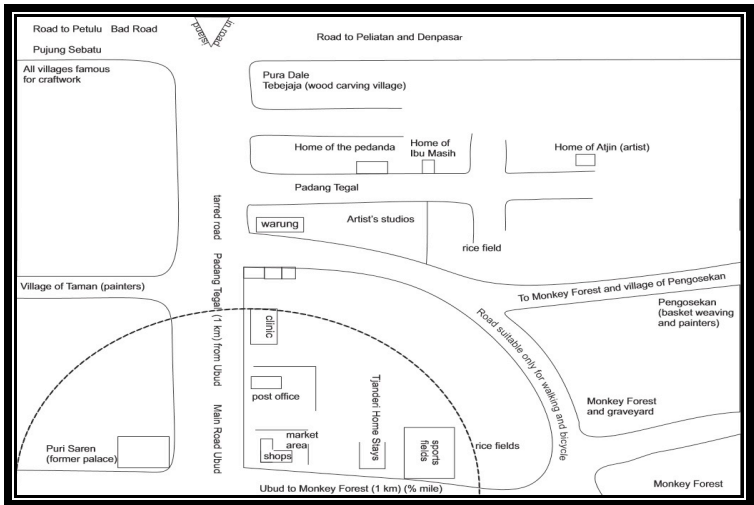

Gambar 5.2. Peta Sketsa Ubud Tahun 1974 Sumber: The Making of Ubud, Richard Mann, 2013 


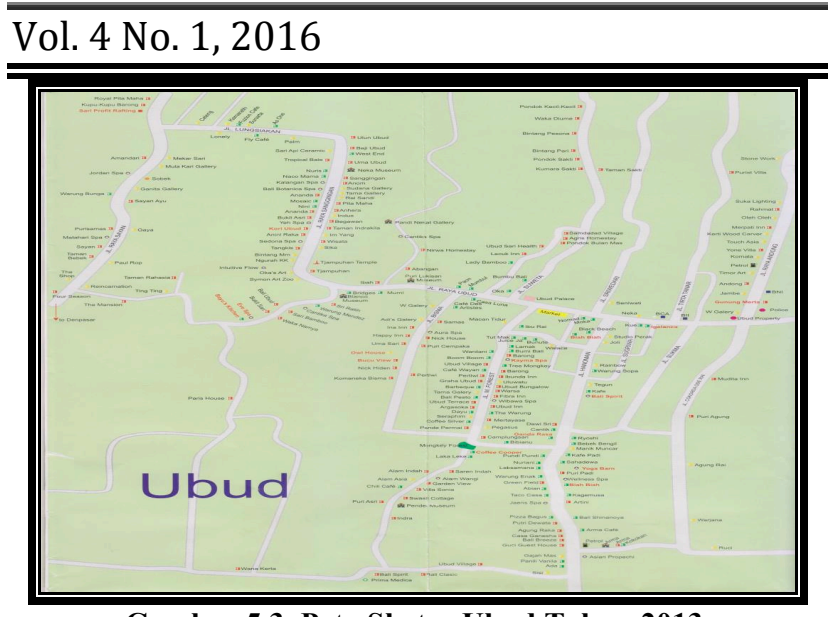

Gambar 5.3. Peta Sketsa Ubud Tahun 2013

Sumber: Free Bali Map, Edisi April-Juni 2013

Gambar 5.2 merupakan peta Ubud tahun 1974, pada gambar tersebut terlihat bahwa pada tahun 1974 hanya terdapat sebuah pondok wisata yaitu Tjanderi Homestay yang terletak di Jalan Wenara Wana. Selebihnya adalah rumah orang-orang penting yang tinggal di Ubud. Kemungkinan wisatawan pada tahun tersebut dapat tinggal di rumah orang-orang penting ini karena terbatasnya pondok wisata yang ada.

Namun bila dibandingkan dengan tahun 2012, jumlah pondok wisata yang ada di Ubud telah menjamur. Ini terbukti melalui jumlah pondok wisata yang terdata di Polsek Ubud tahun 2012 telah mencapai 445 pondok wisata. Hal ini juga jelas terlihat pada gambar 5.3, dimana ini merupakan gambaran Ubud saat ini yang disesaki oleh usahausaha pondok wisata. Jenis-jenis pondok wisata yang muncul pun semakin beragam seperti homestay, house, villa, inn, cottage, bungalow dan accommodation.

Salah satu wilayah di Ubud dengan pondok wisata terbanyak berada di kawasan Jalan Wenara Wana yang merupakan golden area dari Ubud. Disebut demikian karena daerah tersebut berdekatan dengan beberapa daya tarik wisata yang terkenal di Ubud seperti Puri Ubud, Taman Wisata Wenara Wana (Monkey Forest), Museum Puri Lukisan, Pasar Ubud dan lain-lain.

\section{b. Karakteristik pondok wisata di Ubud}

Pondok wisata yang berada di Ubud dapat dibagi menjadi dua tipe yaitu pondok wisata yang dibangun menyatu dengan tempat tinggal pemiliknya dan dibangun terpisah dengan tempat tinggal pemiliknya. Pondok wisata yang terpisah dengan tempat tinggal pemiliknya merupakan pondok wisata yang sudah sangat komersial dan keseluruhan lahan yang dimiliki benar-benar diiperuntukkan untuk kepentingan pondok wisata tersebut.

Lain halnya dengan pondok wisata yang pemiliknya masih tinggal disana, dimana budaya Bali masih terus dipertahankan serta dilestarikan agar tetap dapat dinikmati oleh wisatawan yang menginap di pondok wisatanya. Kamar-kamar yang disediakan bagi wisatawan ini dihiasi dengan ukiran khas arsitektur Bali yang membuat wisatawan betah menginap dan mampu memberikan kesan tersendiri bagi yang pernah tidur didalamnya. berikut.

Seperti yang diungkapkan pemilik Ketut's Place

"Semuanya full style Bali disini. Ya itu lah yang sebenarnya dicari wisatawan-wisatawan yang menginap disini. Apalagi yang dikenal wisatawan dari Bali itu kan budayanya. Nah, ini yang ingin saya tonjolkan dan sekaligus juga saya melestarikan budaya Bali. Wisatawan juga senang dengan model bangunan seperti ini karena mereka merasa sangat eksklusif dengan bangunan yang hanya terdiri dari 1 kamar itu. Banyak wisatawan yang setelah menginap disini bilang ke saya kalau mereka sudah merasa seperti orang Bali karena sempat merasakan tinggal di rumah orang Bali seperti ini" (Suartana, Mei 2013)

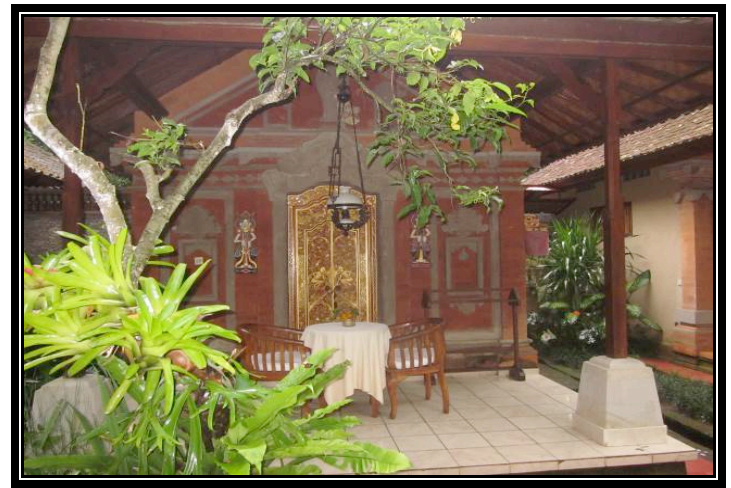

Gambar 5.4. Tampilan Luar Kamar Ketut's Place Sumber: hasil observasi , 2013

Namun, tak dapat dipungkiri bahwa ada sentuhan-sentuhan modern yang juga diterima oleh para pemilik pondok wisata ini yang kemudian diterapkan pada kamar-kamar yang disediakan untuk wisatawan tersebut. Hal ini dikarenakan tuntutan dari para wisatawan yang juga menginginkan hal tersebut. Salah satu contohnya yaitu seperti kamar yang disediakan oleh Puri Muwa Garden. Tampilan luar dari kamar ini sangat kental dengan ornamen Bali, namun di bagian dalamnya telah terdapat kamar mandi yang cukup luas bahkan hampir mencapai setengah dari bangunan kamar tersebut. Pemilik mengaku bahwa ia merenovasi bangunan tersebut menjadi seperti sekarang ini karena kamar 
mandi yang luas seperti itu sangat disukai oleh wisatawan yang berasal dari Jepang yang merupakan pasar utama dari pondok wisatanya.

Jika areal belakang rumah dari pondok wisata yang menyatu ini cenderung diperuntukkan sebagai kamar dan fasilitas bagi wisatawan yang menginap, lain halnya dengan areal bagian depan dari rumah pemilik pondok wisata tersebut yang biasanya dimanfaatkan sebagai warung kecil dan restoran ataupun dibangun kios-kios yang kemudian disewakan kepada orang lain. Beberapa pondok wisata yang melakukan hal ini diantaranya Puri Muwa Garden, Lecuk Inn, Rumah Roda, Ketut's Place, Puri Ulun Carik dan Lumbung Sari Cottages.

Keunikan lain yang dimiliki oleh pondok wisata di Ubud yaitu dalam hal pemberian nama dari usaha pondok wisatanya. Sebagian besar pondok wisata ini menggunakan nama pemiliknya dalam penamaan tersebut. Bagi mereka ini merupakan kebanggan tersendiri dan agar lebih mudah diingat oleh wisatawan. Walaupun pondok wisata tersebut sudah diwariskan pada anak-anak mereka, nama ini masih tetap dipertahankan sesuai dengan awal berdirinya, seperti yang dijelaskan oleh Sudarta yang merupakan anak pemilik Rumah Roda berikut ini.

"Kalau masalah nama, ini unik sebenarnya. Jadi dulu banyak turis yang menginap di sini, ketika ditanyakan oleh orang-orang dimana kamu menginap? Dimana kamu tidur? turis-turis yang menginap di sini menjawab 'di Rumah Roda'. Nah, orang-orang yang bertanya ini bingung mereka, ada rumah berbentuk Roda di Ubud. Ini pun menarik banyak wisatawan untuk berkunjung kesini. Sebenarnya yang dimaksud turis-turis itu dengan Rumah Roda adalah Rumah Bapak Roda. Karena nama bapak saya adalah Pak Roda. Akhirnya karena sudah terkenal saya pun tetap mempertahankan nama Rumah Roda ini. Dari dulu ini menjadi kebanggan bagi bapak saya karena namanya menjadi terkenal." (Sudarta, Mei 2013)

Walaupun usaha pondok wisata ini merupakan usaha keluarga yang tergolong kecil, ternyata usaha ini juga mampu menyerap tenaga kerja. Jumlah karyawan yang dimiliki masing-masing pondok wisata ini sangat beragam sesuai dengan kebutuhan mereka. Ada perbedaan yang cukup mencolok antara karakteristik karyawan yang bekerja di pondok wisata yang menyatu dengan pemiliknya dan pondok wisata yang dibangun terpisah dengan tempat tinggal pemiliknya.

Umumnya karyawan yang bekerja di pondok wisata yang menyatu dengan pemiliknya merupakan keluarga ataupun orang-orang yang direkomendasikan oleh teman pemilik pondok wisata tersebut. Pendidikan mereka juga tidak terlalu diperhitungkan asalkan mereka mau belajar dan rajin bekerja. Pemilik juga tidak memperdulikan jenis kelamin mereka, namun mereka mengutamakan remaja yang berusia 19-28 tahun.

Berbeda halnya dengan karyawan yang bekerja di pondok wisata yang pemiliknya sudah tidak tinggal di usahanya itu lagi. Karyawan disini direkrut secara profesional dan melalui proses seleksi, tes hingga interview. Mereka yang diterima bekerja merupakan pelamar dengan kualifikasi terbaik. Pengelolaan terhadap mereka yang bekerja disini lebih profesional dan terstruktur karena memang sudah diantisipasi dengan manajemen SDM yang cukup baik.

\section{c. Jejaring pemasaran}

Jejaring pemasaran yang digunakan oleh pondok wisata di Ubud terdiri dari dua jenis, yaitu jejaring yang konvensional dan jejaring yang modern.

1. Jejaring Konvensional/ Tradisional

a) Jejaring guide, adalah kerjasama yang dilakukan antara guide dengan pemilik pondok wisata, sehingga ketika guide tersebut membawa wisatawan untuk menginap di pondok wisata yang bersangkutan, guide tersebut akan mendapatkan komisi sebesar $10 \%$ yang diberikan oleh pemilik pondok wisata sebagai jasa timbal balik. Namun, tak jarang juga ada pondok wisata yang menjalin kerjasama dengan beberapa travel agen. Pondok wisata yang menggunakan jejaring guide ini adalah Lumbung Sari Cottages, Puri Muwa Garden dan Puri Ulun Carik yang terletak di Jalan Wenara Wana, Lecuk Inn dan Rumah Roda di Jalan Kajeng, Taman Sakti, Dharma Sakti Homestay dan Sunarta House Homestay di Jalan Suweta, serta Arsa Homestay dan Wayan Family Homestay di Jalan Hanoman.

b) Jejaring mouth-to-mouth, yang menjadi ujung tombak dari jejaring ini adalah wisatawan yang memperoleh kepuasan setelah mendapat pelayanan terbaik dari pondok wisata tempatnya menginap. Wisatawan ini akan menceritakan pengalamannya dan merekomendasikan pondok wisata yang bersangkutan kepada teman-temannya yang akan berlibur ke Ubud. Semua pondok wisata di wilayah Ubud masih menggunakan jejaring mouth-to-mouth ini sebagai sarana yang ampuh dalam mengisi kamar-kamar kosong yang mereka miliki.

c) Jejaring antar pemilik pondok wisata, walaupun sebenarnya pemilik-pemilik pondok wisata ini saling bersaing dalam merebut perhatian wisatawan untuk 


\section{Vol. 4 No. 1, 2016}

menginap, pada kenyatannya para pemilik pondok wisata ini masih memiliki sebuah hubungan kerjasama, dimana bila pondok wisata tersebut telah penuh dihuni oleh wisatawan dan secara kebetulan ada wisatawan yang ingin menginap, maka wisatawan itu akan di transfer ke pondok wisata lain yang telah diajak bekerjasama. Para pemilik pondok wisata ini secara rutin juga saling bertukar informasi dan menjalin kerjasama dengan pemilik pondok wisata yang lainnya di berbagai kesempatan ketika mereka bertemu, contohnya seperti saat latihan megambel di banjar yang dilakukan oleh perkumpulan ibu-ibu PKK ataupun saat mereka sedang duduk-duduk di warung. Pondok wisata yang mengadakan kerjasama dengan sesama pondok wisata lainnya adalah Rumah Roda, Lecuk Inn, dan Rahayu Bungalows.

2. Jejaring Modern/ Berbasis Online

a) Global Distribution System (GDS), merupakan jaringan agen perjalanan wisata di dunia maya yang memungkinkan Computer Reservation System (CRS) berbagai akomodasi pariwisata dapat terkumpul di satu situs yang sama dan bertemu dengan wisatawan yang mengaksesnya melalui internet. Beberapa situs GDS seperti agoda.com dan booking.com yang banyak digunakan oleh pemilik pondok wisata di Ubud.

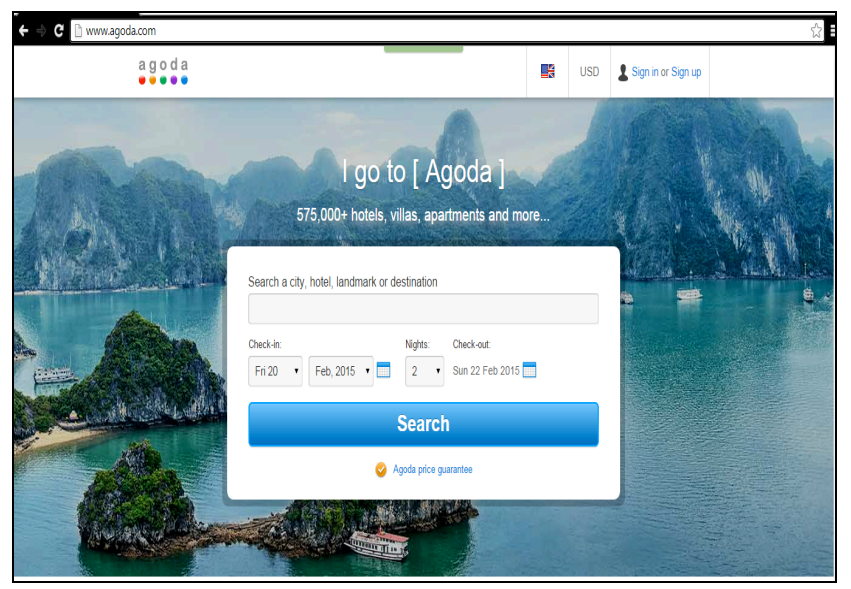

Gambar 5.5

Aplikasi Mobile Agoda.com

Sumber: www.Agoda.com, 2013

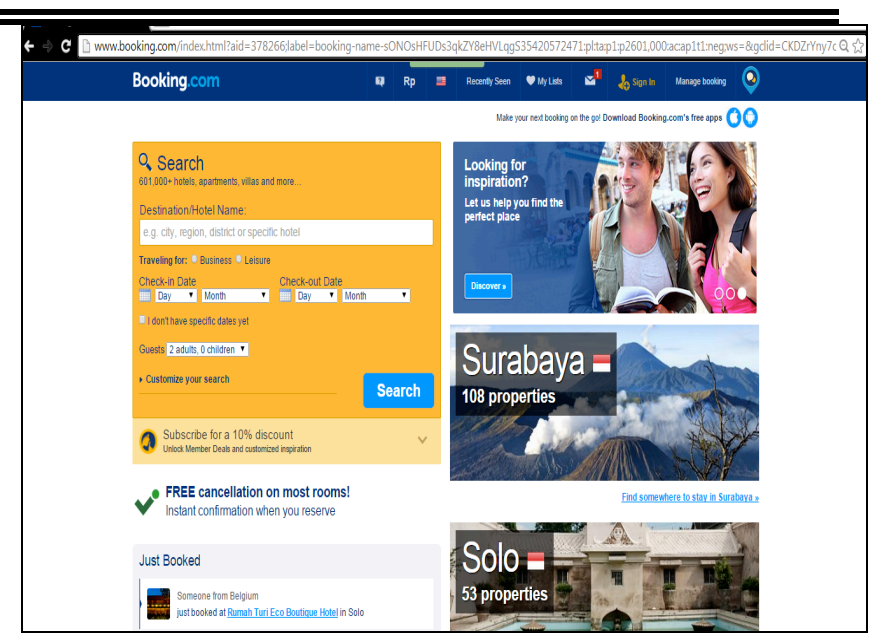

Gambar 5.6. Aplikasi Mobile Booking.com Sumber: www.Booking.com, 2013

i. Jejaring agoda.com, adalah situs online yang menyediakan layanan reservasi properti hotel atau resort secara online yang difokuskan terutama untuk kawasan Asia Pasifik dengan basis operasional yang berada di Bangkok, Singapura dan Filipina. Pondok wisata di Ubud yang menggunakan jasa agoda.com adalah Taman Sakti, Lumbung Sari Cottages, Puri Ulun Carik, Ketut's Place, Rahayu Bungalows dan Indraprastha Bungalowsfax.

ii. Jejaring booking.com, adalah salah satu situs online yang membantu para pemilik akomodasi dalam memasarkan akomodasi yang dimiliki, dimana di dalamnya terdapat informasi lengkap mengenai akomodasi mulai dari harga, diskon, fasilitas dan juga brand yang dimiliki oleh akomodasi. Pondok wisata yang menggunakan jejaring booking.com adalah Lumbung Sari Cottages dan Ketut's Place.

b) Website, beberapa pondok wisata merasa lebih nyaman untuk memasarkan usaha yang dimiliki dengan menggunakan website yang dibuat sendiri. Pondok wisata yang mempunyai website sendiri yaitu Lumbung Sari Cottages (www.lumbungsari.com), Rumah Roda (www.rumahroda.com) dan Ketut's Place (www.ketutsplace.com).

\section{d. Persaingan}

Beberapa persaingan bisnis yang pernah dialami oleh beberapa pondok wisata adalah:

1) Persaingan dalam hal fasilitas, Persaingan yang dirasakan oleh pemilik pondok wisata kebanyakan bersaing dalam hal fasilitas. Banyak pondok wisata yang kalah bersaing karena fasilitas yang dimiliki tergolong kurang dibandingkan pondok wisata lainnya. Persaingan dalam hal fasilitas ini dirasakan 
oleh Sunarta House Homestay di Jalan Suweta dan Rumah Roda di Jalan Kajeng. Salah satu contoh persaingan fasilitas adalah seperti yang dipaparkan oleh Sudarta selaku pemilik Rumah Roda yaitu:

"Kalau persaingan dari segi fasilitas mulai saya rasakan ketika homestay- homestay lain semakin banyak disini. Waktu itu kebanyakan turis yang datang adalah orang asing yang sesuai dengan kebudayaan mandinya ia sangat suka mandi dengan menggunakan shower, turis pun akhirnya mulai meminta shower, namun karena saat itu belum ada listrik, akhirnya saya usahakan dengan membuatkan shower tradisional dari drum yang dilubangi dibagian bawahnya, kemudian ketika listrik sudah tersedia langsung saya gunakan shower yang lebih modern". (Sudarta, Mei 2013)

Dari penuturan pemilik Rumah Roda di atas terlihat bahwa persaingan dari segi fasilitas yang terjadi antar pemilik pondok wisata di Ubud ini sangat ketat. Mereka berusaha untuk memenuhi keinginan wisatawan yang ingin menginap agar pondok wisatanya tidak sepi.

2) Persaingan dalam hal pemasaran (marketing), Persaingan marketing dilakukan oleh manajemen pondok wisata untuk mengemas dan memasarkan produknya agar menarik dan berbeda dari pondok wisata yang lainnya. Contohnya yaitu dengan memiliki website sendiri untuk mempromosikan pondok wisatanya, seperti yang dilakukan oleh Lumbung Sari Cottages, Rumah Roda, dan Ketut's Place. Ada juga yang memasarkan pondok wisatanya melalui email seperti yang dilakukan oleh pondok wisata Taman Sakti. Cara pemasarannya juga cukup unik dimana ketika ada promo terbaru mengenai pondok wisatanya, mereka akan mengirimkan info tersebut melalui email ke wisatawan-wisatawan yang pernah menginap di pondok wisatanya dan diharapkan nantinya email ini bisa diteruskan ke teman-teman wisatawan tersebut.

3) Persaingan dalam hal harga, Persaingan harga dilakukan oleh beberapa pondok wisata untuk menarik wisatawan agar menginap di pondok wisatanya. Contohnya yaitu pada saat low season banyak pondok wisata yang berani menurunkan harga dari harga normal untuk mendapatkan wisatawan. Beberapa pondok wisata yang bersaing dalam hal harga adalah Puri Ulun Carik, Puri Muwa Garden, Indraprastha Bungalows, Wayan Family Homestay, Sunarta House Homestay dan Rumah Roda.

\section{PENUTUP}

\section{a. Simpulan}

Keberadaan pondok wisata di Ubud diawali oleh Tjanderi Homestay. Namun, jika dibandingkan dengan tahun 2012, jumlah pondok wisata di Ubud sudah mengalami peningkatan yang sangat signifikan yaitu sebanyak 445 pondok wisata yang tersebar di seluruh Kecamatan Ubud. Pondok wisata yang terdapat di Ubud ini dapat dikelompokkan menjadi dua, yaitu pondok wisata yang dibangun menyatu dengan tempat tinggal pemiliknya dan pondok wisata yang dibangun terpisah dengan tempat tinggal pemiliknya. Sebagian besar pondok wisata yang dibangun menyatu dengan tempat tinggal pemiliknya mempergunakan areal teba mereka untuk kepentingan usaha tersebut. Sementara itu areal bagian depan rumah mereka lebih banyak dijadikan sebagai warung kecil dan restoran ataupun dibangun kios-kios yang kemudian disewakan kepada orang lain. Meskipun banyak dari areal rumah mereka yang beralih fungsi, ciri khas Bali masih tetap ditonjolkan di usaha-usaha kerakyatan ini. Hal ini dapat dilihat dari ornamen-ornamen ukiran style Bali yang menghiasi bangunanbangunan mereka. Dalam memasarkan pondok wisatanya, para pemilik pondok wisata menggunakan jejaring konvensional atau jejaring tradisional seperti melalui informasi dari mulut ke mulut, jejaring guide, dan jejaring antar pemilik pondok wisata. Pemasaran secara konvensional ini juga dikombinasikan dengan jejaring modern melalui media online yaitu dengan membuat website sendiri ataupun menggunakan Global Distribution System (GDS) seperti agoda.com dan booking.com. Banyaknya jumlah pondok wisata di Ubud ini akhirnya menimbulkan persaingan di antara pemilik pondok wisata tersebut. Beberapa bentuk persaingan yang dialami oleh pemilik pondok wisata di Ubud adalah persaingan dalam hal fasilitas, persaingan dalam hal pemasaran (marketing), dan persaingan dalam hal harga.

\section{b. Saran}

1) Bagi Keberlangsungan Usaha Pondok Wisata

Keberadaan pondok wisata di Ubud saat ini berada dalam keadaan terancam oleh kehadiran hotel berbintang yang mewah, di mana hotel berbintang mampu memberikan fasilitas yang lebih baik dengan harga yang murah dibandingkan dengan pondok wisata yang berskala kecil. Oleh karena itu, pihak yang memiliki peran besar harus memberdayakan masyarakat lokal dalam pengembangan akomodasi pariwisata di Ubud. 
Vol. 4 No. 1, 2016

2) Untuk Tindak Lanjut Penelitian Ini

Ada beberapa hal yang perlu ditindaklanjuti dari penelitian ini, yaitu peneliti harus menambah sampel pondok wisata yang akan diteliti, agar bisa menghasilkan pemetaan persebaran pondok wisata yang ada di Ubud secara menyeluruh.

\section{DAFTAR PUSTAKA}

Gian, I Gede. 2013. Aktivitas Wisatawan Eropa First Timer dan Repeater di Desa Ubud (Suatu Kajian Sosial Budaya). Bali : Universitas Udayana.

http://agoda.com/ diakses pada 28 Mei 2013

http://tripadvisor.co.id/MobileHotelReviewSearch-g297701d1997161-Rumah Roda-

Ubud_Bali.html?reviewsOpen=true\#mtreview_117457198 diakses pada 24 Mei 2013

Mann, Richard. 2013. The Making of Ubud. Gateway Books International.

Moleong, Lexy. 2005. Metodologi Penelitian Kualitatif. Bandung: PT Renaja Rosdakarya.

Perda Provinsi Daerah Tingkat I Bali No. 13

Polsek Ubud. 2012. Data Jumlah Perusahaan Perkantoran, Pabrik, Jasa Perhotelan dan Restoran. Bali.

Sukana, Made. 2002. Keberadaan Usaha Pondok Wisata di Kelurahan Kuta Kabupaten Badung. Bali : Universitas Udayana. Denpasar: Udayana University Press. Tahun 1989 tentang Usaha Pondok Wisata.

Tyas, Lintang Ayu. 2008. Pengelolaan Pondok Wisata Ramah Lingkungan di Kawasan Ubud, Provinsi Bali. Tesis, Ilmu Lingkungan: Universitas Gajah Mada. 